\title{
ANALISIS KURVA SURVIVAL KAPLAN MEIER MENGGUNAKAN UJI LOG RANK (Studi Kasus :Pasien Penyakit Jantung Koroner di RSUD Undata Palu)
}

\author{
Arianti Suhartini ${ }^{1}$, Rita Rahmawati ${ }^{2}$, Suparti $^{3}$ \\ 1,2,3 Departemen Statistika, Fakultas Sains dan Matematika, Universitas Diponegoro \\ e-mail : ritarahmawati@gmail.com
}

\begin{abstract}
Coronary heart disease is one of the leading causes of death in the world, including Indonesia. Based on doctor-diagnosed interviews, coronary heart disease's prevalence in Indonesia on 2013 is $0,5 \%$ and based on a doctor-diagnosed is 1,5\%. Central Sulawesi is ranked first and second for prevalence based on doctordiagnosed interviews and doctor-diagnosed. The high number of people with coronary heart disease caused by lack of self-awareness in lifestyle changes. One of the parameters used to assess the success of treatment is the probability of survival. Survival analysis is a data analysis where the outcome of the variables studied is the time until an event occurs. This study raised the problem of survival of coronary heart patients at Undata Palu Hospital which is the main referral hospital for Central Sulawesi region. This research uses nonparametric method that is Kaplan Meier and Log Rank Test based on six factors are age, gender, stadium, disease status, complication and status of anemia. Nonparametric methods do not follow a particular distribution for survival time. Kaplan Meier's survival curve will describe the patient's characteristics of survival probability and followed by a Log Rank test to see if there are differences between curves. The result of analysis and discussion based on Log Rank test result showed that the factors of age, sex and disease status differ significantly.
\end{abstract}

Keywords: Coronary heart disease, RSUD Undata Palu, Kaplan Meier analysis, Log Rank test.

\section{PENDAHULUAN}

Penyakit jantung koroner (PJK) adalah gangguan fungsi jantung akibat otot jantung kekurangan darah karena adanya penyempitan pembuluh darah koroner (Depkes RI, 2013).PJK adalah salah satu penyebab kematian nomor satu di dunia berdasarkan riset wawancara terdiagnosis dokter dan terdiagnosis dokter. Berdasarkan wawancara terdiagnosis dokter, prevalensi penyakit jantung koroner di Indonesia tahun 2013 sebesar $0,5 \%$ atau diperkirakan sekitar 883.447 orang, dan berdasarkan terdiagnosis dokter atau gejala sebesar 1,5\% atau diperkirakan sekitar 2.650.340 orang (Kemenkes RI, 2014).

Tingginya jumlah penderita PJK disebabkan karena kurangnya kesadaran diri masyarakat dalam perubahan gaya hidup, misalnya kebiasaan merokok, pola makan yang banyak mengandung lemak serta rendah serat, kurang olahraga, kegemukan, dan stres berpotensi besar akan mengalami penyakit jantung.

Prevalensi jantung koroner berdasarkan wawancara terdiagnosis dokter tertinggi di Sulawesi Tengah (0,8\%) diikuti Sulawesi Utara, DKI Jakarta, dan Aceh masing-masing 0,7 persen. Sementara prevalensi jantung koroner menurut diagnosis atau gejala tertinggi di Nusa Tenggara Timur (4,4\%), diikuti Sulawesi Tengah (3,8\%), Sulawesi Selatan (2,9\%), dan Sulawesi Barat (2,6\%) (Depkes RI, 2013). Dari prevalensi berdasarkan wawancara terdiagnosis dokter dan terdiagnosis dokter, Provinsi Sulawesi Tengah menduduki peringkat pertama dan kedua. Salah satu rumah sakit yang berada di Provinsi Sulawesi dan menjadi rujukan utama adalah RSUD Undata Palu.

Berdasarkan penelitian didapatkan faktor risiko penyakit jantung, yang terdiri dari faktor risiko yang tidak dapat dimodifikasi dan dapat dimodifikasi. Faktor risiko yang tidak dapat dimodifikasi adalah faktor risiko yang tidak dapat dilakukan intervensi, karena sudah 
merupakan karakteristik seseorang dari awal mula kehidupannya. Faktor risiko yang tidak dapat dimodifikasi pada PJK yaitu riwayat keluarga, umur, dan jenis kelamin.Sedangkan faktor risiko yang dapat dimodifikasi adalah faktor risiko yang dapat dilakukan intervensi untuk mencegah terjadinya suatu penyakit. Dalam kasus PJK, faktor risiko yang dapat dimodifikasi yaitu hipertensi, diabetes melitus, dislipidemia, merokok, dan obesitas (Onny dalam Herman et al., 2015).

Analisis statistika yang sering digunakan pada bidang kesehatan untuk mengetahui ketahanan hidup seseorang adalah analisis survival. Analisis survival merupakan analisis mengenai data yang diperoleh dari catatan waktu yang dicapai suatu obyek sampai terjadinya peristiwa khusus (failure event).Salah satu metode yang sering digunakan dalam analisis survival nonparametrik adalah analisis Kaplan Meier yang dilanjutkan dengan uji Log Rank. Analisis Kaplan Meier digunakan untuk mengestimasi fungsi survival. Kemudian dari estimasi fungsi survival dapat dibentuk kurva survival Kaplan Meier. Sedangkan uji Log Rank digunakan untuk menguji apakah terdapat perbedaan atau tidak dalam kurva survival Kaplan Meier pada variabel-variabel yang mempunyai kategori dua atau lebih(Kleinbaum dan Klein, 2005).

Berdasarkan pemaparan diatas, maka penelitian ini menggunakan analisis Kaplan Meier dan Uji Log Rank untuk mengetahui perbedaan kurva survivalpada setiap kategori variabelusia, jenis kelamin, stadium, status penyakit, komplikasi dan status anemia, beserta probabilitas ketahanan hidup pada data survival pasien PJK di RSUD Undata Palu.

\section{TINJAUANPUSTAKA}

\subsection{Analisis Survival}

Menurut Kleinbaum dan Klein (2005), analisis survival merupakan kumpulan metode statistika yang digunakan untuk menganalisis data di mana outcome variabel yang diteliti adalah waktu sampai suatu kejadian (event) muncul. Tiga hal yang harus diperhatikan dalam menentukan waktu kegagalan menurut Cox dan Oakes (1984) dalam Inayati dan Purnami (2015), adalah:

1. Waktu awal (starting point) pada penelitian tidak ambigu.

2. Skala pengukuran sebagai bagian dari waktu (measurement scale for the passage of time) yang konsisten.

3. Kejelasan definisi kejadian akhir (ending event of interest) pada penelitian.

\subsection{Data Tersensor}

Penyensoran adalah salah satu langkah yang harus dilakukan untuk mengatasi ketidaklengkapan suatu data pengamatan. Penyensoran terjadi apabila kita mempunyai informasi tentang waktu survival individu, tetapi tidak diketahui secara pasti waktu survivalnya, maka data tersebut termasuk data tersensor. Menurut Kleinbaum dan Klein (2005) terdapat tiga penyebab terjadinya data tersensor, yaitu:

1. Individu tidak mengalami kejadian yang diteliti sampai akhir pengamatan,

2. Individu yang hilang dari pengamatan selama masa penelitian,

3. Individu mengundurkan diri dari penelitian karena kematian (jika kematian bukan kejadian yang diteliti) atau alasan lainnya. 


\section{3. $\quad$ Fungsi Survival dan Fungsi Hazard}

Menurut Kleinbaum dan Klein (2005) pada analisis survival terdapat dua macam fungsi utama yaitu fungsi survival $(S(t))$ dan fungsi hazard $(h(t))$. Fungsi survival $S(t)$ adalah probabilitas suatu objek bertahan setelah waktu ke-t, dinyatakan sebagai berikut:

$$
S(t)=P(T>t) \quad t \geq 0
$$

Fungsi hazard $\mathrm{h}(\mathrm{t})$ merupakan probabilitas suatu individu gagal pada interval waktu t. Dengan demikian fungsi hazard dapat diartikan sebagai kebalikan dari fungsi survival.

$$
h(t)=\lim _{\Delta t \rightarrow 0} \frac{\mathrm{P}(\mathrm{t} \leq \mathrm{T}<t+\Delta t \mid T \geq t)}{\Delta \mathrm{t}}
$$

Sehingga hubungan antara fungsi survival dan fungsi hazard dapat dinyatakan sebagai berikut:

$$
h(t)=\frac{f(t)}{\mathrm{S}(\mathrm{t})}
$$

\subsection{Kurva Survival Kaplan Meier dan Uji Log Rank}

Menurut Kleinbaum dan Klein (2005) analisis Kaplan Meier digunakan untuk menaksir fungsi survival. Berikut merupakan persamaan umum dari fungsi survival yang digunakan untuk membentuk kurva survival Kaplan Meier.

dimana,

$$
\hat{\mathrm{S}}\left(t_{(j)}\right)=\hat{\mathrm{S}}\left(t_{(j-1)} \times \widehat{P}_{r}\left(T>t_{(j)} \mid T \geq t_{(j)}\right)\right.
$$

$$
\hat{\mathrm{S}}\left(t_{(j-1)}\right)=\prod_{i=1}^{j-1} \widehat{P}_{r}\left(T>t_{(j)} \mid T \geq t_{(j)}\right)
$$

Hasil kurva survival Kaplan Meier yang terbentuk, kemudian dibandingkan apakah terdapat perbedaan antar kurva survival menggunakan uji Log Rank. Uji Log Rank merupakan uji yang digunakan untuk membandingkan kurva survival dalam grup yang berbeda. Dengan hipotesis untuk uji Log Rank sebagai berikut:

$\mathrm{H}_{0}$ : tidak ada perbedaan antar kurva survival

$\mathrm{H}_{1}$ : paling sedikit ada satu perbedaan antar kurva survival

Statistik uji yang digunakan dalam uji Log Rank terbagi menjadi uji Log Rank dua grup dan uji Log Rank lebih dari dua grup. Statistik uji untuk uji Log Rank dua grup adalah sebagai berikut:

$$
\text { Log Rank statistics }=\frac{\left(O_{i}-E_{i}\right)^{2}}{\operatorname{Var}\left(O_{i}-E_{i}\right)}
$$

Statistik uji untuk uji Log Rank lebih dari dua grup adalah sebagai berikut.

Log Rank statistics $=\boldsymbol{d}^{\prime} \boldsymbol{V}^{-\mathbf{1}} \boldsymbol{d}$ atau dengan rumus pendekatan Log Rank statistics

$$
X^{2} \approx \sum_{i}^{G} \frac{\left(O_{i}-E_{i}\right)^{2}}{E_{i}}
$$

Hipotesis $\mathrm{H}_{0}$ akan ditolak, jika nilai p-value kurang dari $\alpha$ atau Log Rank statistics $\approx$ $\chi^{2}{ }_{\text {hitung }}$ hitunglebih besar dari $\chi^{2}{ }_{a, d f}$ dengan derajat bebas sama dengan $G-1$.

\subsection{Penyakit Jantung Koroner}

Penyakit jantung koroner adalah suatu kelainan yang disebabkan oleh penyempitan dan penyumbatan pembuluh arteri koroner pada organ jantung. Arteri koroner merupakan pembuluh darah yang menyediakan darah bagi jantung. Penyempitan dan penyumbatan arteri koroner menyebabkan terganggunya aliran darah ke jantung. Terjadinya penyempitan arteri koroner dimulai dengan terjadinya aterosklerosis (kekakuan arteri) 
maupun yang sudah terjadi penimbunan lemak (plak) pada dinding arteri koroner, baik disertai gejala klinis atau tanpa gejala sekalipun. Aterosklerosis adalah penyempitan dan penebalan pembuluh darah manusia yang disebabkan penumpukan plak ateromatus. Plak Ateromatus terdiri dari lemak, kolestrol, kalsium dan fibrin (zat dalam darah). Aterosklerosis merupakan penyebab penyakit jantung koroner yang terbanyak yaitu $98 \%$ sedangkan sisanya akibat spasme dan kelainan arteri (2\%) (Jafar, 2011).

\section{METODE PENELITIAN}

\subsection{Sumber Data dan Variabel Penelitian}

Data yang digunakan dalam penelitian Tugas Akhir ini adalah data sekunder yang diperoleh dari data rekam medis pasien penyakit jantung koroner (PJK) pada tanggal 1 Januari 2015 sampai dengan 31 Desember 2017 di Rumah Sakit Umum Daerah (RSUD) Undata Palu.

\subsection{Variabel Penelitian}

Variabel yang digunakan adalah lama waktu survival atau tahan hidup, status, usia, jenis kelamin, stadium penyakit pasien yang dilihat dari tingkat aterosklerosisnya, pasien menderita PJK sebagai penyakit utama atau penyerta, komplikasi terhadap penyakit lain atau tidak serta status anemia pasien.

\subsection{Tahapan Analisis Data}

1. Menjelaskan karakteristik pasien PJK menggunakan statistika deskriptif untuk variabel yang bersifat kontinu dan pie chart untuk variabel yang bersifat kategorik.

2. Menentukan dan mengurutkan data ketahanan hidup dari nilai terkecil hingga terbesar.

3. Menentukan data tersensor dan tidak tersensor.

4. Menghitung estimasi ketahanan untuk tiap-tiap individu yang masuk pada pengamatan secara keseluruhan.

5. Menghitung estimasi ketahanan untuk tiap-tiap individu yang masuk pada pengamatan berdasarkan kategori variabel.

6. Menggambarkan kurva survival Kaplan Meier pasien PJK berdasarkan kategori variabel-variabel yang mempengaruhi.

7. Menguji perbedaan kurva survival pasien PJK berdasarkan hasil pada langkah sebelumnya dengan uji Log Rank.

8. Melakukan interpretasi terhadap hasil yang diperoleh berdasarkan tujuan penelitian.

\section{HASIL DAN PEMBAHASAN}

\subsection{Analisis Statistika Deskriptif}

Statistika deskriptif digunakan untuk menggambarkan karakteristik berdasarkan faktor-faktor yang diduga mempengaruhi survival pasien PJK di RSUD Undata Palu. Tabel 1 menyatakan hasil statistika deskriptif yang bersifat kontinu.

Tabel 1. Statistika Deskriptif Waktu Survival Pasien

\begin{tabular}{cccccccccc}
\hline Variabel & N & $\begin{array}{c}\text { Rata- } \\
\text { Rata }\end{array}$ & Min & Max & $\mathbf{Q}_{1}$ & $\mathbf{Q}_{2}$ & $\mathbf{Q}_{3}$ & $\begin{array}{c}\text { Deviasi } \\
\text { Standar }\end{array}$ & Modus \\
\hline Waktu & 469 & 36,25 & 0 & 773 & 3 & 5 & 9 & 108,681 & 4 \\
$\begin{array}{c}\text { Survival (T) } \\
\text { Usia (X) }\end{array}$ & 469 & 61,01 & 0 & 88 & 55 & 63 & 68 & 11,015 & 57 \\
\hline
\end{tabular}


Berdasarkan Tabel 1, dari total 469 pasien PJK yang menjalani rawat inap di RSUD Undata Palu, pasien PJK memiliki rata-rata waktu survival sekitar 36 hari dengan waktu terpendek 0 hari dan paling lama 773 hari. Pasien paling banyak melakukan rawat ini selama 4 hari. Ketahanan hidup pasien PJK dapat diprediksi berdasarkan faktor usia. Usia pasien dicatat ketika pertama kali datang ke rumah sakit selama periode penelitian. Berdasarkan Tabel 1, pasien PJK yang menjalani rawat inap rata-rata berumur 61 tahun dengan usia 0 tahun dan 88 tahun sebagai usia termuda dan tertua. Sementara itu, karakteristik pasien PJK yang menjalani rawat inap paling banyak adalah berusia 57 tahun.

Tabel 2.Crosstab Variabel Independen

\begin{tabular}{|c|c|c|c|c|c|c|c|}
\hline \multirow{2}{*}{ Variabel } & \multirow{2}{*}{ Kategori } & \multirow{2}{*}{$\begin{array}{l}\text { Jumlah } \\
\text { Pasien }\end{array}$} & \multicolumn{4}{|c|}{ Status Pasien } & \multirow{2}{*}{$\begin{array}{c}\text { Total } \\
\%\end{array}$} \\
\hline & & & Hidup & $\%$ & Meninggal & $\%$ & \\
\hline \multirow{2}{*}{$\begin{array}{c}\text { Jenis } \\
\text { Kelamin }\end{array}$} & Laki-laki & 274 & 256 & $93,4 \%$ & 18 & $6,6 \%$ & $100 \%$ \\
\hline & Perempuan & 195 & 174 & $89,2 \%$ & 21 & $10,8 \%$ & $100 \%$ \\
\hline \multirow{3}{*}{ Stadium } & Ringan & 51 & 51 & $100 \%$ & 0 & $0 \%$ & $100 \%$ \\
\hline & Sedang & 302 & 277 & $91,7 \%$ & 25 & $8,3 \%$ & $100 \%$ \\
\hline & Berat & 116 & 102 & $87,9 \%$ & 14 & $12,1 \%$ & $100 \%$ \\
\hline \multirow{2}{*}{$\begin{array}{c}\text { Status } \\
\text { Penyakit }\end{array}$} & Utama & 465 & 428 & $92 \%$ & 37 & $8 \%$ & $100 \%$ \\
\hline & Penyerta & 4 & 2 & $50 \%$ & 2 & $50 \%$ & $100 \%$ \\
\hline \multirow{2}{*}{ Komplikasi } & Tidak Ada & 33 & 33 & $100 \%$ & 0 & $0 \%$ & $100 \%$ \\
\hline & Ada & 436 & 397 & $91,1 \%$ & 39 & $8,9 \%$ & $100 \%$ \\
\hline \multirow{2}{*}{$\begin{array}{c}\text { Status } \\
\text { Anemia }\end{array}$} & $\begin{array}{c}\text { Tidak } \\
\text { Menderita }\end{array}$ & 462 & 424 & $91,8 \%$ & 38 & $8,2 \%$ & $100 \%$ \\
\hline & Menderita & 7 & 6 & $85,7 \%$ & 1 & $14,3 \%$ & $100 \%$ \\
\hline
\end{tabular}
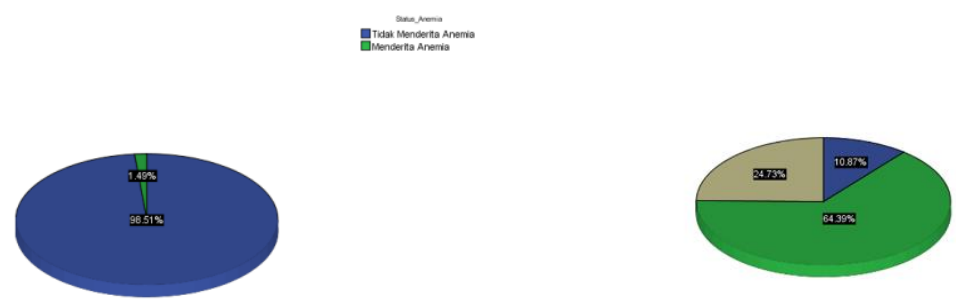

Gambar 1.Karakteristik Pasien PJK berdasarkan Jenis Kelamin
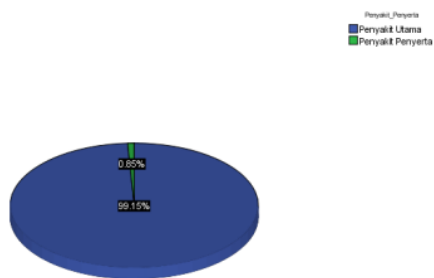

Gambar 3.Karakteristik Pasien PJK berdasarkan Status Penyakit
Gambar 2.Karakteristik Pasien PJK berdasarkan Stadium
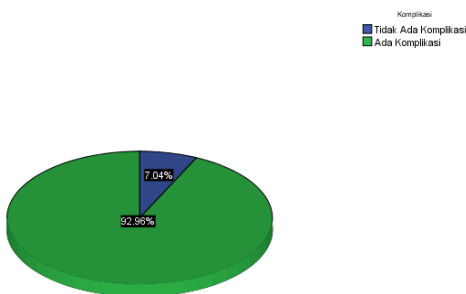

Gambar 4.Karakteristik Pasien PJK berdasarkan Komplikasi 


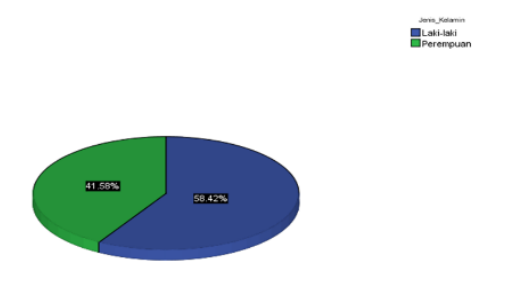

Gambar 5.Karakteristik Pasien PJK berdasarkan Status Anemia

Gambar 1 menunjukkan bahwa mayoritas pasien PJK berjenis kelamin laki-laki sebanyak 274 pasien $(58,42 \%)$. Banyaknya pasien PJK yang berjenis kelamin laki-laki diduga berhubungan dengan gaya hidup yang tidak sehat seperti merokok. Pada Gambar 2, secara umum persentase pasien PJK dengan stadium aterosklerosis sedang memiliki total peresentase yang paling besar yaitu $64,39 \%$ dari 469 pasien. Selanjutnya pasien PJK dengan stadium aterosklerosis berat dan aterosklerosis ringan menempati posisi kedua dan ketiga dengan persentase sebesar 24,73\% dan 10,87\%.Berdasarkan Gambar 3 dapat dilihat hampir seluruh kejadian PJK menjadi penyakit utama bagi pasien dengan persentase 99,15\%. Sedangkan persentase PJK sebagai penyerta hanya 0,85\%. Pada Gambar 4, pasien PJK yang mengalami komplikasi lebih banyak dibandingkan dengan yang tidak mengalami komplikasi, dengan persentase secara berurut sebesar 92,96\% dan 7,04\%.Gambar 5 menunjukkan bahwa 98,51\% pasien PJK tidak mengalami anemia, dan 1,49\% mengalami anemia.

Berdasarkan hasil crosstab pada Tabel 2, persentase kematian terbesar berada pada pasien PJK berjenis kelamin perempuan sebanyak 21 pasien (10,8\%) dari 195 pasien perempuan, pasien dengan stadium ateroskeloris berat merupakan penyebab kematian terbesar dari pasien PJK sebanyak 14 pasien $(12,1 \%)$ dari 102 pasien pada stadium tersebut, pasien PJK yang meninggal karena PJK sebagai penyakit penyerta lebih besar dari pada PJK sebagai penyakit utama yaitu $50 \%$ dibanding $8 \%$, persentase pasien PJK yang meninggal karena mengalami komplikasi adalah 8,9\% dan pasien PJK yang menderita anemia memiliki persentase kematian lebih tinggi yaitu sebanyak 1 pasien $(14,3 \%)$ dari total 6 pasien.

\subsection{Analisis dan Kurva Survival Kaplan Meier}

Kurva survival Kaplan Meier digunakan untuk mengetahui karakteristik survival pasien PJK berdasarkan faktor-faktor yang diduga mempengaruhi ketahanan hidup pasien PJK yaitu usia, jenis kelamin, stadium, status penyakit, komplikasi dan status anemia.

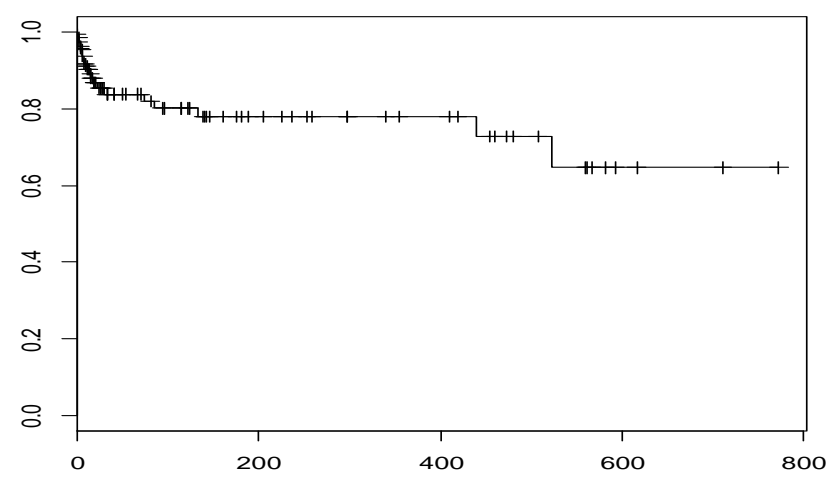

Gambar 6. Kurva Survival Kaplan Meier Pasien Penyakit Jantung Koroner

Karakteristik kurva survival yang disajikan oleh kurva survival Kaplan Meier pada Gambar 6 merupakan gambaran karakteristik kurva survival secara umum. Dapat dilihat 
bahwa kurva turun secara lambat, hal ini dikarenakan banyak data tersensor. Artinya banyak pasien yang tidak mengalami event atau masih bertahan hidup selama tiga tahun. Peluang survival pasien PJK di RSUD Undata Palu masih sedang yaitu berkisar antara 0,6 hingga 1.

Gambar 7 menunjukkan bahwa kurva survival pasien yang berusia $<15$ tahun dan pasien yang berusia 15-64 tahun saling berhimpitan, sedangkan kurva survival pasien yang berusia $>64$ tahun berada dibawah kurva survival pasien dengan dua kelompok usia lainnya. Hal ini menunjukkan bahwa probabilitas survival pasien PJK yang berusia >64 tahun lebih rendah daripada pasien dengan kelompok usia $<15$ tahun dan 15-64 tahun sehingga diduga terdapat perbedaan waktu survival pasien PJK dalam menjalani perawatan berdasarkan variabel usia.

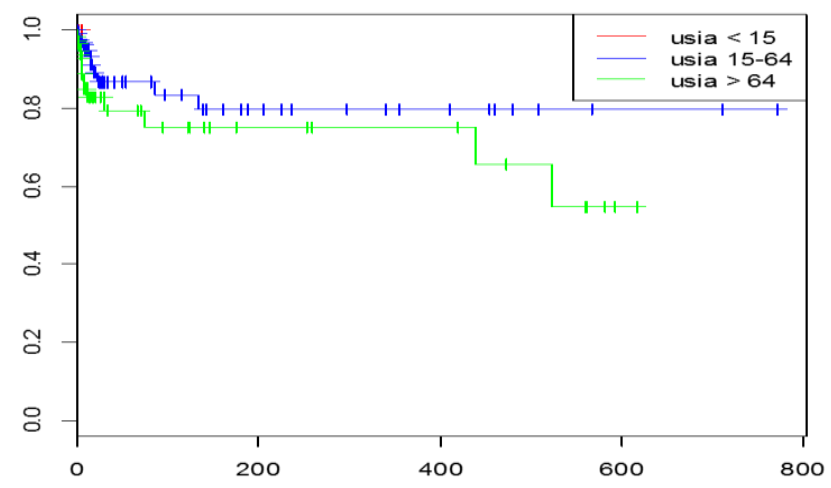

Gambar 7. Kurva Survival Kaplan Meier Berdasarkan Usia

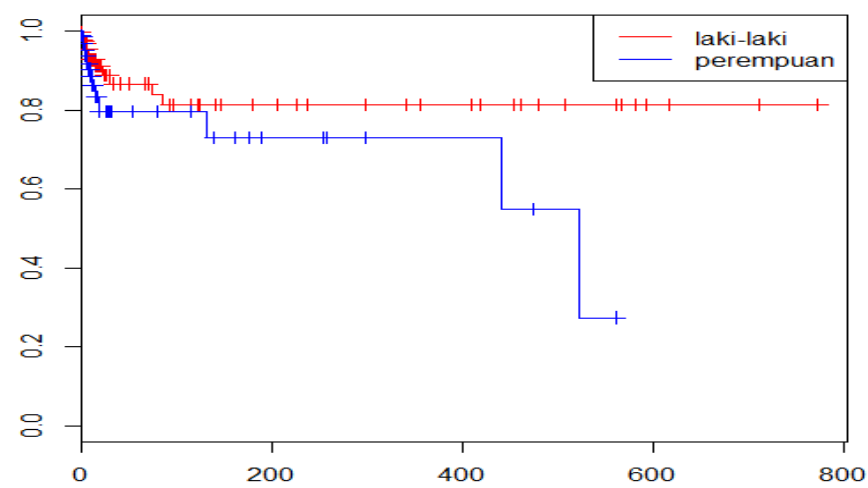

Gambar 8. Kurva Survival Kaplan Meier Berdasarkan Jenis Kelamin

Berdasarkan Gambar 8, terlihat bahwa kurva survival tersebut tidak saling berhimpitan dimana garis merah menunjukkan kurva pasien PJK yang berjenis kelamin laki-laki dan garis biru menunjukkan kurva pasien PJK yang berjenis kelamin perempuan. Jadi, diduga terdapat perbedaan waktu survival pasien PJK yang berjenis kelamin laki-laki dengan pasien yang berjenis kelamin perempuan. 


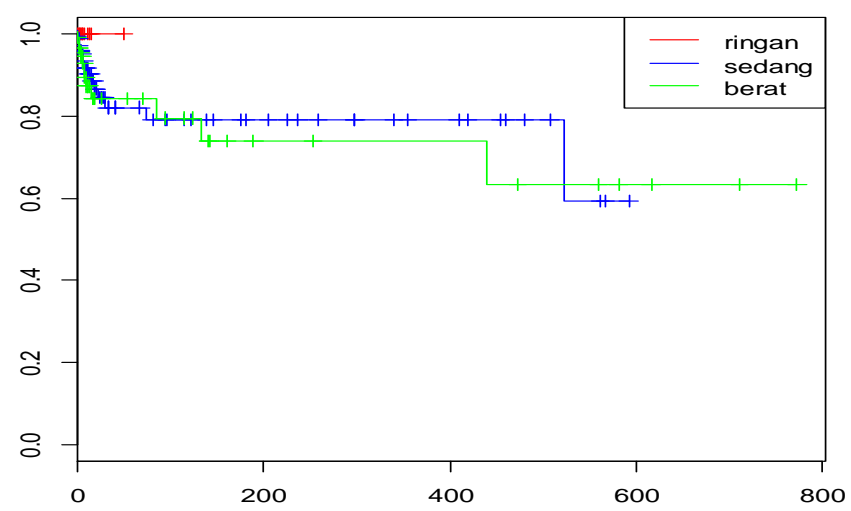

Gambar 9. Kurva Survival Kaplan Meier Berdasarkan Stadium

Dari Gambar 9, dapat dilihat bahwa kurva Kaplan Meier pada awal masuk rumah sakit sampai 800 hari, probabilitas ketahanan hidup pasien untuk stadium aterosklerosis ringan, sedang dan berat masih sedang yaitu antara 0,5 hingga 1, artinya sebagian besar pasien dengan ketiga stadium tersebut masih bertahan hidup selama tiga tahun. Sedangkan kurva survival untuk stadium aterosklerosis sedang pada waktu awal masuk rumah sakit hingga 200 hari turun secara perlahan, artinya probabilitas ketahanan hidupnya semakin menurun. Kemudian setelah 200 hari kurva survival terlihat konstan hingga di 500 hari, setelahnya turun secara cepat hingga hari ke-600. Hal ini menunjukkan setelah 600 hari, probabilitas ketahanan hidup pasien rendah. Berdasarkan penjelasan tersebut diduga terdapat perbedaan kurva survival untuk stadium aterosklerosis sedang dengan kedua stadium yang lain.

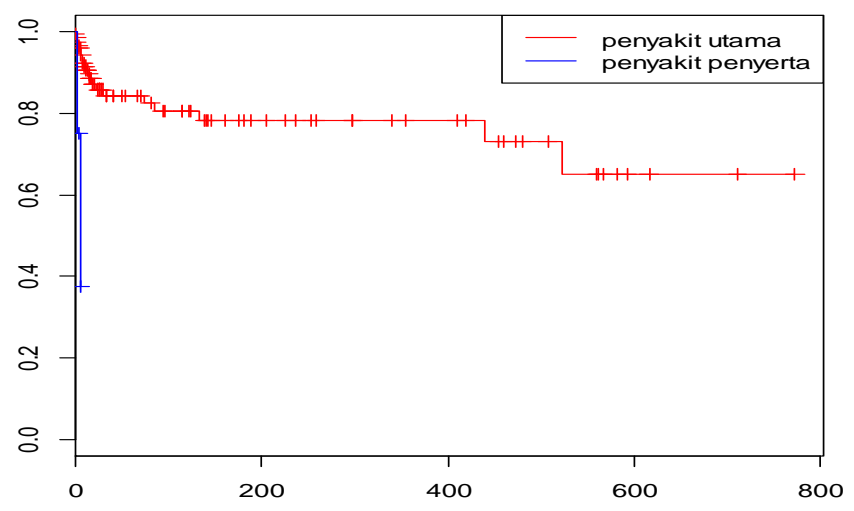

Gambar 10. Kurva Survival Kaplan Meier Berdasarkan Status Penyakit

Berdasarkan Gambar 10, dapat dilihat secara umum kurva survival untuk pasien dengan PJK sebagai penyakit penyerta berada dibawah kurva survival dengan PJK sebagai penyakit utama. Hal ini menunjukkan probabilitas ketahanan hidup pasien PJK sebagai penyakit utama lebih tinggi daripada sebagai penyakit penyerta. Jika dilihat dari aspek medis, kurva survival ini sesuai. Kondisi ini disebabkan karena selama penelitian ditemukan penyakit lain yang mematikan pada pasien dengan PJK sebagai penyakit penyerta. Sedangkan jika diagnosis PJK sebagai penyakit utama masih berada pada stadium dini, probabilitas ketahanan hidupnya masih tinggi. Sehingga diduga penyakit penyerta tidak mempengaruhi probabilitas ketahanan hidup pasien PJK. 


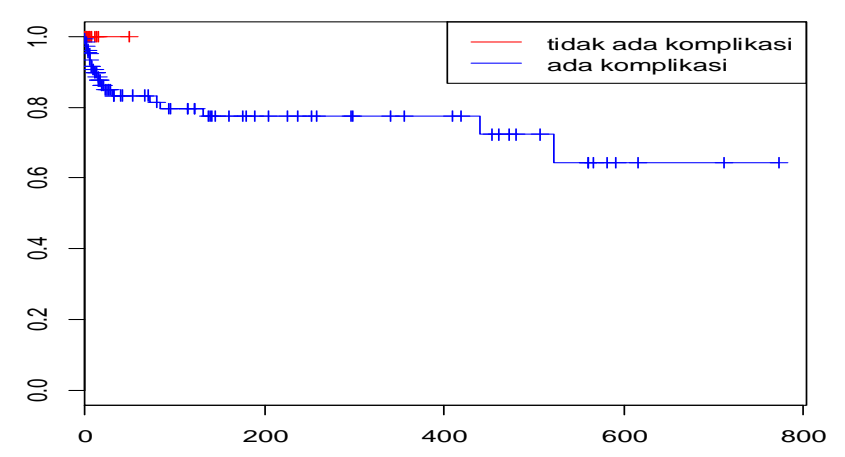

Gambar 11. Kurva Survival Kaplan Meier Berdasarkan Faktor Komplikasi

Gambar 11 menunjkkan pada awal masuk rumah sakit hingga 50 hari, kurva survival pasien yang tidak mengalami komplikasi cenderung konstan dan probabilitas ketahanan hidupnya masih tinggi. Sedangkan kurva survival untuk pasien yang mengalami komplikasi, pada awal masuk rumah sakit hingga akhir penelitian mengalami penurunan. Artinya seiring bertambahnya waktu survival, probabilitas ketahanan hidup pasien PJK semakin rendah. Dari penjelasan yang telah diuraikan maka diduga terdapat perbedaan kurva survival pada pasien yang mengalami komplikasi dan tidak mengalami komplikasi.

Pada Gambar 12, kurva dengan garis merah untuk pasien PJK yang tidak mengalami anemia dan kurva dengan garis biru untuk pasien yang mengalami anemia berbeda. Pada awal masuk rumah sakit hingga akhir penelitian, probabilitas pasien yang tidak mengalami anemia lebih rendah dari pada pasien yang mengalami anemia. Hal ini menunjukkan bahwa secara grafis ada perbedaan kurva survival antara pasien PJK yang tidak mengalami anemia dengan pasien yang mengalami anemia.

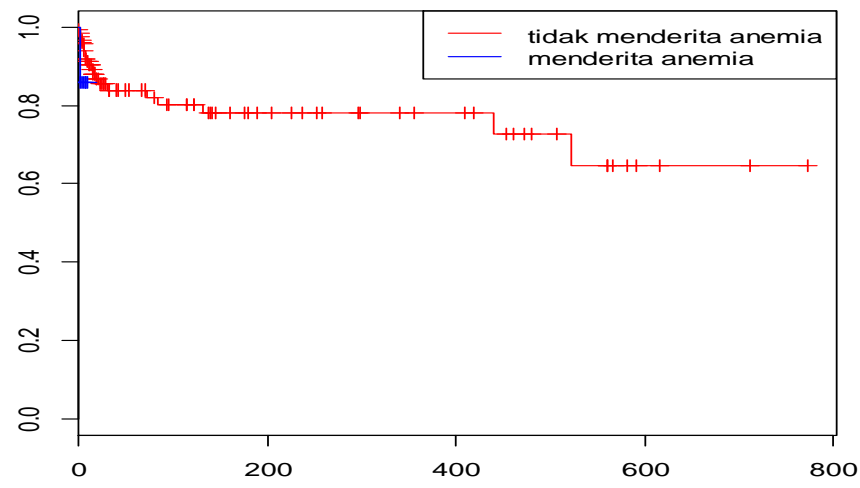

Gambar 12. Kurva Survival Kaplan Meier Berdasarkan Status Anemia

\subsection{Uji Log Rank}

Selanjutnya, untuk mendukung hipotesa pada kurva survival Kaplan Meier yang telah disajikan pada subbab sebelumnya, maka perlu dilakukan uji log rank. Uji log rank digunakan untuk mengetahui apakah terdapat perbedaan antar kurva survival dalam grup tiap faktor.

Berikut ini merupakan hasil uji Log Rank berdasarkan faktor-faktor yang diduga mempengaruhi pasien PJK: 
Tabel 3. Uji Log Rank

\begin{tabular}{cccc}
\hline Variabel & Log rank & Df & $P$-value \\
\hline Usia & 6,6 & 2 & 0,0368 \\
Jenis Kelamin & 4,1 & 1 & 0,0418 \\
Stadium & 3 & 2 & 0,22 \\
Status Penyakit & 21,2 & 1 & $4,08 \mathrm{e}-06$ \\
Komplikasi & 1,6 & 1 & 0,199 \\
Status Anemia & 0,8 & 1 & 0,369 \\
\hline
\end{tabular}

Berdasarkan hasil uji log rank pada Tabel 3 dapat diketahui waktu survival pasien PJK berdasarkan variabel usia,jenis kelamin dan status penyakit berbeda secara signifikan karena $p$-value dari tiga variabel tersebut lebih kecil dari $\alpha$ yakni sebesar 0,05 . Sedangkan, waktu survival pasien PJK berdasarkan variabel stadium, komplikasi dan status anemia tidak berbeda secara signifikan.

\section{KESIMPULAN}

Berdasarkan hasil analisis dan pembahasan pada penelitian ini, kesimpulan yang didapatkan adalah sebagai berikut.

1. Hasil analisis statistika deskriptif memberikan informasi bahwa pasien PJK mampu bertahan hidup hingga 2 tahun. Rata-rata pasien PJK berusia 61 tahun. Sedangkan, berdasarkan hasil kurva survival Kaplan Meier secara umum memberikan gambaran bahwa peluang survival pasien PJK di RSUD Undata Palu masih sedang berkisar antara 0,6 hingga 1 .

2. Secara deskriptif berdasarkan kurva survival Kaplan Meier dan uji Log Rank pada variabel stadium, komplikasi dan status anemia menunjukkan bahwa tidak terdapat perbedaan kurva survival yang artinya pada masing-masing antar kategorinya dalam variabel tidak berbeda dan tidak akan mempengaruhi probabilitas ketahanan hidup pasien PJK sedangkan pada variabel usia, jenis kelamin, dan status penyakit terdapat perbedaan kurva survival, yaitu:

- Probabilitas ketahanan hidup pasien untuk kelompok usia > 64 tahun lebih rendah dibandingkan kelompok usia 15-64 tahun dan kelompok usia 15-64 tahun lebih rendah dari kelompok usia $<15$ tahun.

- Probabilitas pasien dengan jenis kelamin perempuan lebih rendah dari pada pasien dengan jenis kelamin laki-laki.

- Probabilitas ketahanan hidup pasien yang menderita PJK sebagai penyakit penyerta lebih rendah dari pada pasien yang menderita PJK sebagai penyakit utama.

\section{DAFTAR PUSTAKA}

[Depkes RI] Departemen Kesehatan Republik Indonesia. 2013. Laporan Hasil Riset Kesehatan Dasar (Riskesdas) 2013. Jakarta.

Herman, S. I., Syukri, M., dan Efrida. 2015. Hubungan Faktor Risiko yang dapat Dimodifikasi dengan Kejadian Penyakit Jantung Koroner di RS Dr. M. Djamil Padang. Jurnal Kesehatan Andalas Vol. 4, No. 2 : Hal 369-375.

Inayati, K. D., dan Purnami, S. W. 2015. Analisis Survival Nonparametrik Pada Pasien Kanker Serviks di RSUD Dr. Soetomo Surabaya Menggunakan Metode Kaplan Meier dan Uji Log Rank. Jurnal Sains dan Seni ITS Vol. 4, No.2: Hal. 199-204.

Jafar, N. 2011. Penyakit Jantung Koroner. http://repository.unhas.ac.id/handle/ 123456789/2688. Diakses : 1 April 2018. 
[Kemenkes RI] Kementrian Kesehatan Republik Indonesia. 2014. Info DATIN Pusat Data dan Informasi Kementrian Kesehatan RI Situasi Kesehatan Jantung. Jakarta.

Kleinbaum, D. G., dan Klein, M. 2005. Survival Analysis A Self-Learning Text 2nd Edition. London: Springer. 